\section{Origin of granitoid rocks}

CLAYBURN ET AL. ${ }^{1}$ have recently stated that "Moorbath" has presented $\mathrm{Pb}-\mathrm{Sr}$ isotopic evidence that a mantle component is present in granitic rocks of all ages, a feature which can be considered indicative of continuous primary continental accretion". This is an unintentional partial misrepresentation of my views on this subject, which have also been misquoted in other recent papers. This confusion arises because Clayburn et al., as well as many other workers, tend to use and interpret the broad, all-encompassing term 'granitoid' interchangeably with the specific term 'granitic', thereby frequently lumping together rock units of totally different petrogenetic lineages, for which there is no justification in most of the published data from isotope geology or experimental petrology ${ }^{3-6}$.

Published isotopic evidence demonstrates that true granites of any geological age in continental tectonic environments frequently have a significant or major component derived from older sialic crust. Indeed, many granites (s.s.) may be the products of pure crustal anatexis (see ref. 7). In contrast, calc-alkaline granitoids (such as diorite, tonalite, granodiorite) of any geological age-and especially voluminous orthogneisses of the major Precambrian shield areas-appear to be predominantly derived from basic lithosphere with mantle-like geochemical and isotopic characteristics, although in some tectonic environments there may be isotopic and other evidence for significant crustal contamination of mantle-derived magmas (see ref. 8).

In this connection, the view of Allègre and Othman ${ }^{9}$ (quoted by Clayburn et al. ${ }^{1}$ ) that granitoids younger than $\sim 2,000 \mathrm{Myr}$ contain predominantly recycled crustal component but that older ones are juvenile mantle extracts makes no petrogenetic, tectonic or other distinction between true granites and calc-alkaline, intermediate rocks, whilst the limited sampling of these authors for $\mathrm{Nd}-\mathrm{Sr}$ isotopic analysis of granitoids from a great variety of Precambrian and Phanerozoic environments cannot be regarded as adequate, in my view, to justify generalized global modelling of crust-mantle evolution. Every geological province, of whatever age, must be investigated in detail and treated as an individual case study, whilst isotopic data should not be discussed in isolation from geological, petrological and structural evidence in complex terrains. Initial $\mathrm{Sr}, \mathrm{Nd}$ and $\mathrm{Pb}$ isotopic ratios of granitoid rocks are not directly dependent on their age but on their petrogenesis which, in turn, is closely related to the presence or absence of older sialic crust.
I have no argument with the overall isotopic conclusions of Clayburn et al. ${ }^{1}$ that the granitoid rocks of the Etive Igneous Complex, ranging from calcalkaline to granitic types, were produced as a result of melting of both contemporary mantle and lower continental crust, or with their interpretation that the process represents combined primary crustal growth coupled with assimilation of older stabilized continental crust. This type of situation is currently being modelled from many other igneous provinces. However, I ask these and other workers on crustal evolution to be specific and unambiguous in their use and interpretation of accepted terminology. Only by specifying precisely the investigated rock types can confusion and misunderstanding in the study of the great, polygenetic family of crust-forming granitoid rocks be avoided.

\section{S. MOORBATH}

Department of Geology

and Mineralogy,

University of Oxford,

Parks Road,

Oxford OX1 3PR, UK

1. Clayburn, J. A. P., Harmon, R. S., Pankhurst, R. J. \& Brown, J. F. Nature 303, 492-497 (1983).

2. Moorbath, S. Chem. Geol. 23, 151-187 (1977); Phil. Trans. R. Soc. A288, 401-413 (1978).

3. Stern, C. R. Huang, W. L. \& Wyllie, P. J. Earth planet. Sci. Lett. 28, 189-196 (1975).

4. Wyllie, P. J., Huang, W. L., Stern, C. R. \& Maaloe, S. Can. J. Earth Sci. 13, 1007-1019 (1976)

Wyllie, P. J. Tectonophysics 43, 41-71 (1977)

6. Wyllie, P. J. Geol. Rdsch. 70, 128-153 (1981)

7. Moorbath, S., Taylor, P. N. \& Goodwin, R. Geochim. cosmochim. Acta 45, 1051-1060 (1981).

8. Taylor, P. N., Moorbath, S., Goodwin, R. \& Petrykowski, A. C. Geochim. cosmochim. Acta 44, 1437-1453 (1980).

9. Allègre, C. J. \& Othman, D. B. Nature 286, 335-342 (1980).

PANKHURST REPLIES-We thank Moorbath for his comments on the introduction to our article ${ }^{1}$ on the isotope geochemistry of the Etive Igneous Complex and apologize for any unintended misrepresentation of his view caused by a poor choice of words.

Our purpose was simply to set the scene by referring to two extreme schools of thought on the origin of granitoid rocks (s.l.) which have polarized around the older and necessarily restricted isotope data. Many workers have taken the primitive isotope characteristics of calc-alkaline granitoids (and sometimes true granites as well) to indicate primary crustal accretion solely through the processes of mantle melting and magma differentiation, despite warnings that a basic rather than ultrabasic immediate source for the magmas could be inferred from trace element data (see refs 2,3 ).
We fully concur with Dr Moorbath in his criticisms of indiscriminate grouping of petrogenetically different granitoids by Allègre and Othman ${ }^{4}$, but, again, we were only concerned to draw attention to diverse views, however securely (or otherwise) founded. It remains of significance that our conclusions for the Etive Igneous Complex, which is of undoubtedly calcalkaline parentage, recognize an appreciable (though difficult to quantify) component derived from much older lower crust and subjacent basic lithosphere as distinct from contemporary (Caledonian) mantle.

British Antarctic Survey,

\section{R. J. PANKHURST}

Natural Environment

Research Council,

c/o Institute of

Geological Sciences,

64 Gray's Inn Road,

London WC1X 8NG, UK

1. Clayburn, J. A. P., Harmon, R. S., Pankhurst, R. J. \& Brown, J. F. Nature 303, 492-497 (1983).

2. O'Nions, R. K. \& Pankhurst, R. J. Earth planet. Sci. Lett. 38, 211-236 (1978).

3. Pankhurst, R. J. in Origin of Granite Batholiths: Geochemical Evidence (eds Atherton, M. P. \& Tarney, J.) 18-33 (Shiva, Orpington, 1979).

4. Allègre, C. J. \& Othman, D. B. Nature 286, 335-342 $(1980)$.

\section{Amines and secretory pathways}

THE output of ACTH precursors from At T-20 cells (a mouse pituitary line) has been shown by Moore et al. ${ }^{1}$ to be enhanced by chloroquine $(200 \mu \mathrm{M})$. The cells normally synthesize a 30,000 molecular weight $(30 \mathrm{~K})$ precursor, from which they proteolytically cleave two forms of ACTH, $13 \mathrm{~K}$ and $4.5 \mathrm{~K}$, which differ in their glycosylation. The precursor is externalized constitutively, as are other molecules such as a viral membrane glycoprotein, gp70. The cleaved products are mainly stored in secretory granules and discharged in the presence of a secretagogue, such as 8-bromo-cyclic AMP. Since chloroquine reduces storage of products, Moore et al. conclude that molecules of precursor are diverted from the secretory to the constitutive pathway. They suggest that ACTH packaging "may be another example in which a low intraorganelle $p \mathrm{H}$ is required for correct sorting of protein molecules". Chloroquine possibly "prevents the delivery of precursor ACTH to the secretory granule, which contains the specific protease", perhaps by elevation of the granule $p \mathrm{H}$, as in packaging of lysosomal 